\title{
The role of IL-7 in Immunity and Cancer
}

\author{
JACK LIN ${ }^{1}$, ZIWEN ZHU ${ }^{2}$, HUAPING XIAO ${ }^{1,3}$, MARK R. WAKEFIELD ${ }^{2}$, \\ VIVI A. DING ${ }^{1}$, QIAN BAI ${ }^{2}$ and YUJIANG FANG ${ }^{1,2}$ \\ ${ }^{1}$ Department of Microbiology, Immunology and Pathology, Des Moines University, Des Moines, IA, U.S.A.; \\ ${ }^{2}$ Department of Surgery, University of Missouri School of Medicine, Columbia, MO, U.S.A.; \\ ${ }^{3}$ The Affiliated Hospital of Xiangnan University, Chenzhou, P.R. China
}

\begin{abstract}
Interleukin-7 (IL-7) is a cytokine that has been known since long in immunology, mainly regarding its effects on T-cells and B-cells. IL-7 has been demonstrated to be necessary for both B-cell and T-cell proliferation and lack of IL-7 causes immature immune cell arrest. Interestingly, in recent years, certain studies have strongly suggested that the role of IL-7 is far beyond the field of immunology, it might have direct or indirect effect on cancer. This review aims to summarize the role of IL-7 in immunity and its role in the pathogenesis of neoplasia.
\end{abstract}

Interleukin-7 (IL-7) was discovered in 1980s. It is one of the members of IL-2 superfamily (1). IL-2 superfamily includes IL-2, IL-4, IL-7, IL-9, IL-15 and IL-21. It binds to receptors with a common $\gamma$ chain subunit (2-4). In addition to a common $\gamma$ chain subunit, the receptor for IL-7 (IL-7R) requires an IL-7R $\alpha$ chain in order for binding to take place. Due to the frequency of the common $\gamma$ chain subunit, the presence of the IL-7 receptor $\alpha$ chain is a better identifier for when IL-7 will actually bind to a receptor. IL-7-receptor binding results in phosphorylation of tyrosine residues on the receptor. This leads to activation of JAK1 or JAK3 depending on the cell type, which later activates many downstream signaling pathways including STAT5a/b, PI3 Kinase, and SRC kinases as shown in Figure 1 (2-6). It is well-known that IL-7 plays a critical role in the development of B-cells and T-cells (7). In recent years, increasing evidence suggests that

This article is freely accessible online.

Correspondence to: Dr. Yujiang Fang, Department of Microbiology, Immunology \& Pathology, Des Moines University College of Osteopathic Medicine, Des Moines, IA, 50312, U.S.A. Tel: +1515 2711435, Fax: +1 5152711543, e-mail: yujiang.fang@dmu.edu

Key Words: IL-7, immunity cancer, review.
IL-7 may also play a pivotal role in the pathogenesis of neoplasia. This review will highlight the updated information regarding the role of IL-7 in immunity and cancer.

\section{The Role of IL-7 in the Development of B-cells}

IL-7 has been found to play a critical role in the development of B-cells. While not directly due to IL-7, there seems to be some relation between IL-7 and the pre-B-cell receptor in the survival, proliferation and differentiation of B-cells (8-10). This relationship should be further examined, as current models demonstrate IL-7 not being required for human Bcell development (11) despite its necessity in mice models (12). In relation to B-cell development in neonates, there appears to be a strong effect of increasing B-cell proliferation in cord blood $\mathrm{CD} 34^{+}$cells when exposed to IL2 and IL-7 (8-10). Administration of IL-7 to normal mice leads to an increase in pre-B-cells and mature B-cells (13-15). Administration of IL-7 to lymphocyte deficient mice leads to an increase in mature B-cells (8-10).

These B-cell-promoting effects of IL-7 are seen in stark contrast to some effects that appear to promote B-cell apoptosis. $\mathrm{CD}^{+} 5^{+} \mathrm{B}$ lymphocytes generally are associated with HIV1 infection. Current treatments sometimes involve some regiment of IL-7. However, it appears that IL-7 induces the apoptosis of these $\mathrm{CD}^{+} 5^{+} \mathrm{B}$-cells (16). In addition to these pro-apoptotic effects, IL-7 also appears to stunt B-cell maturation in HIV infected patients. This was demonstrated by a marked increase in these immature B-cells when given an administration of IL-7 (17). These effects of IL-7 on immature B-cells does not come necessarily as a surprise. Human pre-B-cells do have IL-7 receptors and respond to IL7 when presented in the presence of stromal cells (18).

Additionally, IL-7 can act as a trophic factor in many developing B-cells. BCL2 family members and certain membrane proteins have been shown to have a role in this effect, however, the exact mechanism is still unclear (19). 
IL-7 also works with stromal derived factor1 (SDF1), stem cell factor (SCF), and fms-related tyrosine kinase 3 ligand (FLT3LG) in order to regulate B-cell development (20-22).

Mature B-cells are usually unable to respond to IL-7, however, a small group of peripheral B-cells have been shown to be responsive. In vitro studies have demonstrated that B-cell receptor antigen diversity occurs during development, but further changes can happen, and are controlled by recombinase-activating genes (20-22). Oddly enough, in vitro generation of B-cells did not require IL-7 at all, despite the overwhelming amount of evidence that IL-7 is required for $\mathrm{B}$-cell maturation in vivo $(23,24)$.

\section{The Role of IL-7 in the Development of T-cells}

T-cell development occurs through several stages in the thymus. Immature T-cells need to reach sufficient levels because their development has several stages known as positive and negative selection, contributing to the loss of $98 \%$ of Tcells (25). In relation to $\mathrm{T}$ cell development in general, triple negative precursors migrate into the thymus where they mature. As they mature, they go through the cortex into the medulla, and it is from here that the single positive T-cells leave to enter the circulation. The thymus is the primary location of T-cell production although T-cells have also been shown to develop in the intestine, aided by IL-7 (26). This development of T cells is also supported by in vitro studies. Where regulation of human $\mathrm{T}$ cell maturation was achieved by decreasing IL-7 and increasing anti-CD3 levels (27). These effects are supported by studies demonstrating how intrathymic $\mathrm{T}$ cell development is dependent in some part on the presence of IL-7 (28). Specifically, IL-7 along with thymic stromal lymphopoietin seem to be necessary for Treg maturation (29).

Similar to B-cells, T cell maturation seems to be stunted by IL-7 in HIV infection women. This has been demonstrated in patients both before HAART treatment and after. This effect seems magnified when patients are coinfected with $\mathrm{HCV}$, as HCV seems to increase circulating IL-7 (30). Oddly enough, this is in contrast to other data suggesting IL-7 restores $\mathrm{T}$ cell diversity (31). Both studies were performed on HIV positive patients and done in recent years. As a result, further studies on the matter need to be conducted.

IL-7 has been demonstrated to enhance thymocyte viability $(32,33)$. IL-7 has anti-apoptotic effects which involve BCL2 associated $\mathrm{X}$ protein $(\mathrm{BAX})$ which is part of the BCL-2 gene family (33). B-cell lymphoma 2 (BCL2) has also been shown to decrease in IL-7 deficient mice, which later caused increased apoptosis (34). Additionally, BCL2 transgene expression in IL-7R deficient mice resulted in restoration of mature T-cells $(35,36)$. This data indicates the regulatory role IL-7 plays in apoptosis via changes to the BCL2 family.

IL-7 appears to be necessary for proper T-cell receptor $\gamma$ locus rearrangement, although IL-7 involvement in other locations is unclear. It appears as if the regulation of this rearrangement occurs through STAT5 histone acetylation $(37,38)$.

\section{Potential Anti-tumor Effects of IL-7}

IL-7 presents antitumor effects in tumors such as glioma, melanoma, lymphoma, leukemia, prostate cancer, and glioblastoma. In vivo administration of IL-7 resulted in a decreased cancer cell growth in murine models. Additionally, the same study demonstrated that graft versus tumor action was promoted in models if the graft is an allogeneic graft that is first T-cell replete (38). This data supports the concept that IL-7 has antitumor properties. IL-7 has been shown to enhance the antitumor effect of interferon- $\gamma$ (IFN $\gamma)$ in rat glioma tumors (39). IL-7 can also induce the production of IL- $1 \alpha$, IL- $1 \beta$, and TNF- $\alpha$ by monocytes. These cytokines promoted IL-7 seem to help inhibits melanoma growth (40). IL-7 also appears to limit lymphopenia-induced proliferation (40). It has also been demonstrated to have a confirmed antitumor immune response. IL-7 has been demonstrated to be the most effective cytokine in increasing cytotoxic CD8+ T lymphocytes (CD8 ${ }^{+}$T-cell) when compared to IL-2 and IL4 (41). It has been demonstrated that long-term tumor antigen specific $\mathrm{CD} 8^{+} \mathrm{T}$-cell responses are enhanced by IL7 treatment (42). Prevention of mutation to IL7R $\alpha$ is of vital importance for preventing leukemia. Namely, it has been demonstrated that a gain-of-function mutation to results in an oncogenic function of the receptor. As a result, an increased propensity of T-cell acute lymphoblastic leukemia occurs (43). These findings suggest that IL-7 can enhance lymphocyte response within tumors.

Prostatic acid Phosphatase (PAP) was fused into various cytokines, including IL-7. In an in vivo study, simultaneous intraperitoneal administration of PAP-fused IL-7, GMCSF, IL-2, and IL-4 resulted in a decreased induction and growth in PAP expressing tumors. This finding suggests that IL-7 in addition to these other cytokines has an antitumor role in prostate cancer (44). The CD47 gene is over expressed in several tumors including glioblastomas. The over-expressed CD47 in many tumors seems to help control tumor growth by increasing expression of IL-7 (45).

After treatment of pediatric sarcomas, immune response is often deteriorated. However, treatment with recombinant human IL-7 as an adjuvant therapy seems to promote immune recovery, as measured by CD4 count recovery (46). Increasing IL-7 responsiveness by increasing IL7R $\alpha$ levels seem to also promote antitumor immunity (47). There is some suggestion that higher T-cell survival could by linked with better antitumor function that is durable. Recent studies have demonstrated that preinfused T-cell clones that possess IL-7R and c-myc are more likely to persist in patients (48). There appears to be great antitumor effect in chimeric IL4 
and IL-7 exodomain fusion. This is a newer treatment, so generation of it as such still requires future clinical trials (49). The antitumor effects of IL-7 does seem to include simply increasing proliferation and antitumor activity of IL$7 \alpha$ (50). It has been shown that adjuvant IL-7 treatment improves antitumor functions in animal models and this seems to be mainly due to an increased IL-6 as well as a magnified Th17 differentiation (51). Finally, it is of interest that IL-7 administration in GMCSF-secreting tumor mice greatly prolonged their survival (52). Thus, IL-7 seems to have an anti-tumor effect in a direct or indirect manner.

\section{Potential Pro-tumor Effects of IL-7}

Interestingly, besides the studies suggesting that IL-7 might have a potential anti-tumor effect, some other studies indicate that IL-7 might also have potential pro-tumor effects. There does appear to be effects IL-7 has on preventing apoptosis by regulating the BCL2 gene family, namely BCL2 Associated $\mathrm{X}$ protein $(\mathrm{BAX})$, in lung cancer and thus promoting its proliferation. However, its exact effects on non-small cell lung cancer is still unclear (53). Additionally, IL-7 appears to promote bladder cancer invasion \& migration via limitation of p27kip (54). The IL-7R gene appears to be an oncogene that is mutated in T-cell acute lymphoblastic leukemia, (43). Future studies are needed to understand the role of these mutations and their effects on cancer.

One study suggests that IL-7 has an important role in the prevention of apoptosis (53). IL-7 and IL-7R induce upregulation of cyclin D1 is required for progression through the $\mathrm{G}_{1}$ phase of the cell cycle. When tumors are present, cyclin D1 expression increases and leads to greater quantities of cells entering $G_{1}$. Significant decrease in cancer cell apoptosis has been shown resulting from the activation of IL-7 and IL-7R. Similarly, qPCR assays have shown increases in the level of anti-apoptotic BCL2 accompanied by the decrease in proapoptotic p53, and a down-regulation of BCL2 Associated X protein. Besides the effect of IL-7 on prevention of apoptosis, IL-7 may also promote cFOS and cJUN activity in cancers such as non-small cell lung cancer (55). Activation of cFOS and cJUN will in turn accelerate proliferation of cells and increase lymphovascular formation (55). Thus, IL-7 seems also to have a potential tumor-promoting effect.

\section{Conclusion}

In this review, the main developmental signaling pathways of IL-7 were discussed, accompanied by the roles that IL-7 may play in immunity and pathogenesis of neoplasia. Since cytokine-based immunotherapy plays an important role in the treatment of advanced malignant tumors, such as renal cell carcinoma and melanoma, it is necessary to expand our understanding of the role of cytokines, such as IL-7, in the

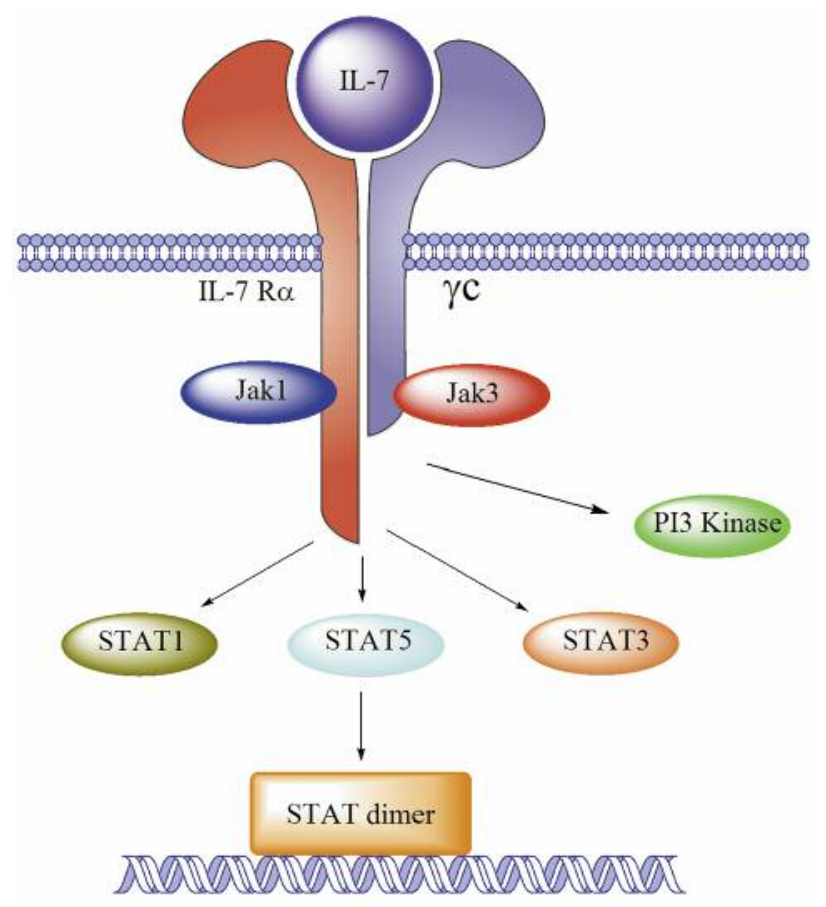

Figure 1. IL-7 signal pathway.

pathogenesis of neoplasia. The role of IL-7 in the pathogenesis of neoplasia seems controversial. A possible explanation for the conflicting evidence found in the literature is that cytokines are found in different levels of balance based on their physiological location, with the degree of neoplastic progression also resulting in differing cytokine expression. Clearly, further intensive studies are needed to elucidate the contexts in which IL-7 functions as a tumor promoter versus as a tumor inhibitor. We are looking forward to the development of safer and more effective cytokine-based immunotherapy to benefit patients with advanced malignancy.

\section{Conflicts of Interest}

The Authors have no conflict of interest.

\section{Acknowledgements}

This work was supported by grants of Yujiang Fang M.D., Ph.D. (IOER 05-14-01, IOER 112-3749 and IOER 112-3114).

\section{References}

1 Fiorentino DF, Bond MW and Mosmann T: Two types of mouse t helper cell. Iv. Th2 clones secrete a factor that inhibits cytokine production by th1 clones. J Exp Med 170(6): 20812095, 1989. 
2 Kondo M, Takeshita T, Higuchi M, Nakamura M, Sudo T, Nishikawa S-L and Sugamura K: Functional participation of the il-2 receptor gamma chain in il-7 receptor complexes. Science 263(5152): 1453-1454, 1994.

3 Noguchi M, Nakamura Y, Russell SM, Ziegler SF, Tsang M, Cao $\mathrm{X}$ and Leonard WJ: Interleukin-2 receptor gamma chain: $\mathrm{A}$ functional component of the interleukin-7 receptor. Science 262(5141): 1877-1880, 1993.

4 Ziegler SF, Morella KK, Anderson D, Kumaki N, Leonard WJ, Cosman D and Baumann H: Reconstitution of a functional interleukin (il)-7 receptor demonstrates that the il-2 receptor $\gamma$ chain is required for il-7 signal transduction. Eur $\mathrm{J}$ Immunol 25(2): 399-404, 1995.

5 Asao H, Okuyama C, Kumaki S, Ishii N, Tsuchiya S, Foster D and Sugamura K: Cutting edge: The common $\gamma$-chain is an indispensable subunit of the il-21 receptor complex. J Immunol 167(1): 1-5, 2001.

6 Ozaki K, Kikly K, Michalovich D, Young PR and Leonard WJ: Cloning of a type i cytokine receptor most related to the il-2 receptor $\beta$ chain. Proc Natl Acad Sci USA 97(21): 11439-11444, 2000.

7 Bazdar DA, Kalinowska M, Panigrahi S and Sieg SF: Recycled il-7 can be delivered to neighboring t cells. J Immunol 194(10): 4698-4704, 2015.

8 Fisher A, Burdet C, Bunce C, Merkenschlager M and Ceredig R: Lymphoproliferative disorders in il-7 transgenic mice: Expansion of immature $b$ cells which retain macrophage potential. Int Immunol 7(3): 415-423, 1995.

9 Mertsching E, Meyer V, Linares J, Lombard-Platet S and Ceredig R: Interleukin-7, a non-redundant potent cytokine whose over-expression massively perturbs b-lymphopoiesis. Int Rev Immunol 16(3-4): 285-308, 1998.

10 Valenzona $\mathrm{H}$, Pointer $\mathrm{R}$, Ceredig $\mathrm{R}$ and Osmond $\mathrm{D}$ : Prelymphomatous $\mathrm{b}$ cell hyperplasia in the bone marrow of interleukin-7 transgenic mice: Precursor b cell dynamics, microenvironmental organization and osteolysis. Exp Hematol 24(13): 1521-1529, 1996.

11 Puel A, Ziegler SF, Buckley RH and Leonard WJ: Defective il7r expression in $\mathrm{t}-\mathrm{b}+\mathrm{nk}+$ severe combined immunodeficiency. Nat Genet 20(4): 394-397, 1998

12 Kohn LA, Hao Q-L, Sasidharan R, Parekh C, Ge S, Zhu Y, Mikkola HK and Crooks GM: Lymphoid priming in human bone marrow begins before expression of cd10 with up-regulation of 1-selectin. Nat Immunol 13(10): 963-971, 2012.

13 Damia G, Komschlies KL, Faltynek CR, Ruscetti FW and Wiltrout RH: Administration of recombinant human interleukin-7 alters the frequency and number of myeloid progenitor cells in the bone marrow and spleen of mice. Blood 79(5): 1121-1129, 1992.

14 Komschlies KL, Gregorio TA, Gruys ME, Back TC, Faltynek $\mathrm{CR}$ and Wiltrout $\mathrm{RH}$ : Administration of recombinant human il-7 to mice alters the composition of b-lineage cells and $t$ cell subsets, enhances t cell function, and induces regression of established metastases. J Immunol 152(12): 5776-5784, 1994.

15 Morrissey PJ, Conlon P, Braddy S, Williams DE, Namen AE and Mochizuki DY: Administration of il-7 to mice with cyclophosphamide-induced lymphopenia accelerates lymphocyte repopulation. J Immunol 146(5): 1547-1552, 1991.

16 Namen AE, Schmierer AE, March CJ, Overell RW, Park LS, Urdal DL and Mochizuki DY: B cell precursor growth-promoting activity. Purification and characterization of a growth factor active on lymphocyte precursors. J Exp Med 167(3): 988-1002, 1988.
17 Malaspina A, Moir S, Ho J, Wang W, Howell ML, O'Shea MA, Roby GA, Rehm CA, Mican JM and Chun T-W: Appearance of immature/transitional $\mathrm{b}$ cells in hiv-infected individuals with advanced disease: Correlation with increased il-7. Proc Natl Acad Sci USA 103(7): 2262-2267, 2006.

18 Dittel BN and LeBien TW: The growth response to il-7 during normal human b cell ontogeny is restricted to b-lineage cells expressing cd34. J Immunol 154(1): 58-67, 1995.

19 Corcoran A, Smart F, Cowling R, Crompton T, Owen M and Venkitaraman A: The interleukin-7 receptor alpha chain transmits distinct signals for proliferation and differentiation during b lymphopoiesis. EMBO J 15(8): 1924, 1996.

20 Ghia P, Gratwohl A, Signer E, Winkler TH, Melchers F and Rolink AG: Immature b cells from human and mouse bone marrow can change their surface light chain expression. Eur $\mathbf{J}$ Immunol 25(11): 3108-3114, 1995.

21 Hertz M and Nemazee D: Bcr ligation induces receptor editing in igm+ igd- bone marrow b cells in vitro. Immunity 6(4): 429436, 1997.

22 Rolink A, Grawunder U, Haasner D, Strasser A and Melchers F: Immature surface ig $+\mathrm{b}$ cells can continue to rearrange kappa and lambda 1 chain gene loci. J Exp Med 178(4): 1263-1270, 1993.

23 Han S, Dillon SR, Zheng B, Shimoda M, Schlissel MS and Kelsoe G: V (d) j recombinase activity in a subset of germinal center b lymphocytes. Science 278(5336): 301-305, 1997.

24 Papavasiliou F, Casellas R, Suh H, Qin X-F, Besmer E, Pelanda $R$, Nemazee D, Rajewsky K and Nussenzweig MC: V (d) j recombination in mature $\mathrm{b}$ cells: A mechanism for altering antibody responses. Science 278(5336): 298-301, 1997.

25 Rodewald H-R and Fehling HJ: Molecular and cellular events in early thymocyte development. Adv Immunol 69: 1-112, 1998.

26 Lefrançois L and Puddington L: Extrathymic intestinal t-cell development: Virtual reality? Immunol Today 16(1): 16-21, 1995.

27 Patel ES, Okada S, Hachey K, Yang L-j, Durum SK, Moreb JS and Chang L-J: Regulation of in vitro human t cell development through interleukin-7 deprivation and anti-cd3 stimulation. BMC Immunol 13(1): 46, 2012.

$28 \mathrm{Yu}$ Q, Erman B, Park J-H, Feigenbaum L and Singer A: Il-7 receptor signals inhibit expression of transcription factors tcf-1, lef-1, and roryt impact on thymocyte development. J Exp Med 200(6): 797-803, 2004.

29 Haas J, Korporal M, Schwarz A, Balint B and Wildemann B: The interleukin-7 receptor $\alpha$ chain contributes to altered homeostasis of regulatory $\mathrm{t}$ cells in multiple sclerosis. Eur $\mathrm{J}$ Immunol 41(3): 845-853, 2011.

30 Kerzerho J, Mcllvaine EJ, Anthony P, Mack WJ, Wang C-H, Frederick T, Operskalski E, Chen Z, Al-Harthi L and Landay A: Impact of hepatitis $\mathrm{c}$ virus on the circulating levels of il-7 in hiv-1 coinfected women. JAIDS J Acq Imm Def 71(2): 172-180, 2016.

31 Morre $\mathrm{M}$ and Beq S: Interleukin-7 and immune reconstitution in cancer patients: A new paradigm for dramatically increasing overall survival. Target Oncol 7(1): 55-68, 2012.

32 Suda T and Zlotnik A: Il-7 maintains the $\mathrm{t}$ cell precursor potential of cd3-cd4-cd8-thymocytes. J Immunol 146(9): 30683073, 1991

33 Kim K, Lee C-k, Sayers TJ, Muegge K and Durum SK: The trophic action of il-7 on pro-t cells: Inhibition of apoptosis of pro-t $1,-\mathrm{t} 2$, and-t 3 cells correlates with bcl-2 and bax levels and is independent of fas and p53 pathways. J Immunol 160(12): 5735-5741, 1998. 
34 von Freeden-Jeffry U, Solvason N, Howard M and Murray R: The earliest $\mathrm{t}$ lineage-committed cells depend on il-7 for bcl-2 expression and normal cell cycle progression. Immunity $7(1)$ : 147-154, 1997.

35 Maraskovsky E, O'Reilly LA, Teepe M, Corcoran LM, Peschon JJ and Strasser A: Bcl-2 can rescue t lymphocyte development in interleukin-7 receptor-deficient mice but not in mutant rag1-/- mice. Cell 89(7): 1011-1019, 1997.

36 Akashi K, Kondo M, von Freeden-Jeffry U, Murray R and Weissman IL: Bcl-2 rescues t lymphopoiesis in interleukin-7 receptor-deficient mice. Cell 89(7): 1033-1041, 1997.

37 Huang J, Durum SK and Muegge K: Cutting edge: Histone acetylation and recombination at the tcr $\gamma$ locus follows il-7 induction. J Immunol 167(11): 6073-6077, 2001.

38 Ye S-K, Agata Y, Lee H-C, Kurooka H, Kitamura T, Shimizu A, Honjo T and Ikuta K: The il-7 receptor controls the accessibility of the tcr $\gamma$ locus by stat 5 and histone acetylation. Immunity 15(5): 813-823, 2001.

39 Fritzell S, Eberstål S, Sandén E, Visse E, Darabi A and Siesjö P: Ifn $\gamma$ in combination with il-7 enhances immunotherapy in two rat glioma models. J Neuroimmunol 258(1): 91-95, 2013.

40 Alderson MR, Tough TW, Ziegler SF and Grabstein KH: Interleukin 7 induces cytokine secretion and tumoricidal activity by human peripheral blood monocytes. J Exp Med 173(4): 923 930, 1991.

41 Lynch DH, Namen AE and Miller RE: In vivo evaluation of the effects of interleukins 2, 4 and 7 on enhancing the immunotherapeutic efficacy of anti-tumor cytotoxic $t$ lymphocytes. Eur J Immunol 21(12): 2977-2985, 1991.

42 Colombetti S, Lévy F and Chapatte L: Il-7 adjuvant treatment enhances long-term tumor antigen-specific cd8+t-cell responses after immunization with recombinant lentivector. Blood 113(26): 6629-6637, 2009.

43 Zenatti PP, Ribeiro D, Li W, Zuurbier L, Silva MC, Paganin M, Tritapoe J, Hixon JA, Silveira AB and Cardoso BA: Oncogenic i17r gain-of-function mutations in childhood t-cell acute lymphoblastic leukemia. Nat Genet 43(10): 932-939, 2011.

44 Fujio K, Watanabe M, Ueki H, Li S-A, Kinoshita R, Ochiai K, Futami J, Watanabe T, Nasu Y and Kumon H: A vaccine strategy with multiple prostatic acid phosphatase-fused cytokines for prostate cancer treatment. Oncol Rep 33(4): 1585-1592, 2015.

45 Boukhari A, Alhosin M, Bronner C, Sagini K, Truchot C, Sick E, Schini-Kerth VB, Andre P, Mely Y and Mousli M: Cd47 activation-induced uhrf1 over-expression is associated with silencing of tumor suppressor gene p16 ink4a in glioblastoma cells. Anticancer Res 35(1): 149-157, 2015.

46 Merchant MS, Bernstein D, Amoako M, Baird K, Fleisher TA, Morre M, Steinberg SM, Sabatino M, Stroncek DF and Venkatesan AM: Adjuvant immunotherapy to improve outcome in high risk pediatric sarcomas. Clin Cancer Res 22(13): 3182-3191, 2016.
47 Johnson CB, Riesenberg BP, May BR, Gilreath SC, Li G, Staveley-O'Carroll KF, Garrett-Mayer E, Mehrotra S, Cole DJ and Rubinstein MP: Effector cd8+ t-cell engraftment and antitumor immunity in lymphodepleted hosts is i17r $\alpha$ dependent. Cancer Immunol Res 3(12): 1364-1374, 2015.

48 Chandran SS, Paria BC, Srivastava AK, Rothermel LD, Stephens DJ and Kammula US: Tumor-specific effector cd8+ $t$ cells that can establish immunological memory in humans after adoptive transfer are marked by expression of il7 receptor and c-myc. Cancer Res 75(16): 3216-3226, 2015.

49 Leen AM, Sukumaran S, Watanabe N, Mohammed S, Keirnan J, Yanagisawa R, Anurathapan U, Rendon D, Heslop HE, Rooney $\mathrm{CM}$, Brenner MK and Vera JF: Reversal of tumor immune inhibition using a chimeric cytokine receptor. Mol Ther 22(6): 1211-1220, 2014.

50 Perna S, Pagliara D, Mahendravada A, Liu H, Brenner M and Savoldo B: Interleukin-7 mediates selective expansion of tumorredirected cytotoxic t lymphocytes (ctls) without enhancement of regulatory t-cell inhibition. Clin Cancer Res 20(1): 131-139, 2014.

51 Pellegrini M, Calzascia T, Elford AR, Shahinian A, Lin AE, Dissanayake D, Dhanji S, Nguyen LT, Gronski MA and Morre M: Adjuvant il-7 antagonizes multiple cellular and molecular inhibitory networks to enhance immunotherapies. Nat Med 15(5): 528-536, 2009.

52 Li B, VanRoey MJ and Jooss K: Recombinant il-7 enhances the potency of gm-csf-secreting tumor cell immunotherapy. Clin Immunol 123(2): 155-165, 2007.

53 Liu Z-H, Wang M-H, Ren H-J, Qu W, Sun L-M, Zhang Q-F, Qiu $\mathrm{X}-\mathrm{S}$ and Wang E-H: Interleukin 7 signaling prevents apoptosis by regulating bcl-2 and bax via the p53 pathway in human nonsmall cell lung cancer cells. Int J Clin Exp Pathol 7(3): 870, 2014.

54 Park SL, Lee E-J, Kim W-J and Moon S-K: P27kip1 is involved in erk1/2-mediated mmp-9 expression via the activation of nf$\mathrm{kb}$ binding in the il-7-induced migration and invasion of 5637 cells. Int J Oncol 44(4): 1349-1356, 2014.

55 Ming J, Zhang Q, Jiang Y, Jiang G and Qiu X: Interleukin 7 and its receptor promote cell proliferation and induce lymphangiogenesis in non-small cell lung cancer. Zhonghua Bing Li Xue Za Zhi 41(8): 511-518, 2012.
Received December 14, 2016

Revised January 28, 2017

Accepted January 31, 2017 